\title{
GEOPHYSICAL STUDIES AND TECTONISM OF THE HELLENIDES
}

\author{
Makris J. \\ University of Hamburg and GeoPro GmbH, 20457 Hamburg, Germany
}

\begin{abstract}
By constraining gravity modelling by Deep Seismic Soundings (DSS) and the Bouguer gravity field of Greece a 3-D density-velocity model of the crust and upper mantle was developed. It was shown that in the north Aegean Trough and the Thermaikos Basins the sediments exceed $7 \mathrm{~km}$ in thickness. The basins along the western Hellenides and the coastal regions of western Greece are filled with sediments of up to $10 \mathrm{~km}$ thickness, including the Prepulia and Alpine metamorphic limestones.

The thickest sedimentary series however, were mapped offshore southwest and southeast of Crete and are of the order of 12 to $14 \mathrm{~km}$. The crust along western Greece and the Peloponnese ranges between 42 and $32 \mathrm{~km}$ thickness while the Aegean region is floored by a stretched continental crust varying between 24 to $26 \mathrm{~km}$ in the north and eastern parts and thins to only $16 \mathrm{~km}$ at the central Cretan Sea.The upper mantle below the Aegean Sea is occupied by a lithothermal system of low density $\left(3.25 \mathrm{gr} / \mathrm{cm}^{3}\right)$ and Vp velocity $(7.7 \mathrm{~km} / \mathrm{s})$, which is associated with the subducted Ionian lithosphere below the Aegean Sea.

Isostasy is generally maintained at crustal and subcrustal levels except for the compressional domain of western Greece and the transition between the Mediterranean Ridge and the continental backstop. The isotherms computed from the Heat Flow density data and the density model showed a significant uplift of the temperature field below the Aegean domain. The $400^{\circ} \mathrm{C}$ isotherm is encountered at less than $10 \mathrm{Km}$ depth. Tectonic deformation is controlled by dextral wrench faulting in the Aegean domain, while western Greece is dominated by compression and crustal shortening. Strike-slip and normal faults accommodate the western Hellenic thrusts and the westwards sliding of the Alpine napes, using the Triassic evaporates as lubricants.
\end{abstract}

\section{Introduction}

In order to protect society from earth hazards and secure the resources for its economic development geologic and geophysical information are basic essentials. In the following, I will present a brief summary of efforts and their results in geophysical mapping the Hellenides by active seismic methods, gravity and geothermal techniques. It will be demonstrated, how the obtained physical parameters can be exploited in producing earth models, needed for understanding the seismicity and the present tectonic activity. It is obvious that the limited space does not permit a thorough discussion. My report therefore has to be understood as the intention to show the road ahead rather than claim completeness.

\section{Active seismic experiments for crustal studies}

In figure one, two colours, red and white, indicate the distribution of seismic profiles that have provided crustal information. White lines are the seismic profiles collected in the 70s and early 80 s. They have been presented in several papers by Makris 1978, Makris and Vees 1977, Makris et al. 1977, Ginzburg et al. 


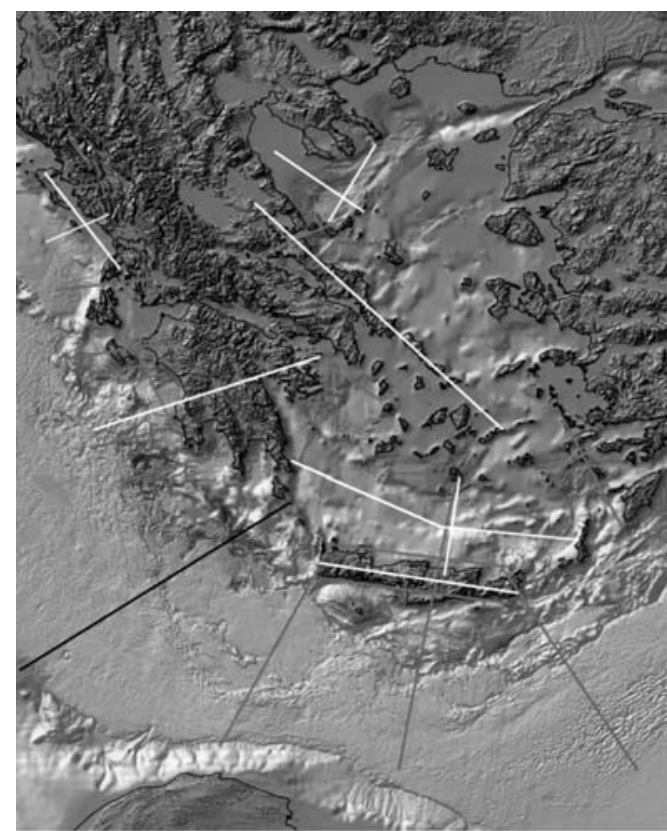

1. WARRP Profiles : 1971 - 1974 - white lines

2. Two ship seismic experiment: De Voogd et al. 1992 - black line 3. WARRP Lines-Greece: between 1994 to 2007 - red lines
Fig. 1: Location of seismic lines recorded in 19711974 and 1982-1984 in white. Red are 2D-lines mapped in 1994 to 2008. In black is a composite line that has been obtained from 2 ships experiments and published by De Voogd et al. in 1992.

1987, Makris and Thiessen 1983. The paper published by Makris 1978 in Tectonophysics gives a summary of these early results. The main shortcoming of those experiments was the limited availability of seismic mobile stations. In most experiments we used 30 MARS 66, 4 channel stations (Berckhemer 1970) that were recording on analogue magnetic tape and were digitized for further processing. The advantage of those days was the use of explosives in generating seismic energy. Up to 1 ton of explosives were fired at sea and the quarry shots recorded from the Mandouthi mines (North Evia) were up to 4 tons large. Seismic signals of very good quality were recorded up to $380 \mathrm{~km}$ distance. Seismic models were computed by forward modelling of two-point ray tracing. These experiments were performed in cooperation and with the support of the Seismological Laboratory of the University of Athens, Prof. A. Galanopoulos, and were funded by the Deutsche Forschungsgemeinschaft (German Research Society).

After a period of experimental inactivity, mainly used in developing new instruments, field operations were resumed from the mid 90s till 1998. The seismic lines observed in this period are shown in red (fig. 1). Field operations were conducted in cooperation with the Hellenic Centre for Marine research (HCMR) and the Geodynamic Institute of the National Observatory of Athens. The 1994 program of western Greece was supported by the Public Petroleum Corporation of Greece (PPC). Results have been partially published by Makris and Chonia 2000, Bonhofff et al. 2001, Makris et al. 2001, Makris and Yegorova 2006 and Papoulia and Makris this volume. The projects were funded by the Deutsche Forschungsgemeinschaft, the EU, and the Public Petroleum Cop. Of Greece and GeoPro- Hamburg, Germany.

In figure 2 four seismic lines are presented. Three are results from the latest profiles using Ocean Bottom Seismographs (OBS) at sea and stand alone seismic stations on land. We have used up to 60 land stations and 50 OBSs at the various experiments, provided by GeoPro, Hamburg and 10 OBS provided by HCMR, Anavissos (Dr. Papoulia). The seismic energy was generated using large airgun arrays, tuned to low frequencies and of 40 to $60 \mathrm{lt}$ volume. 


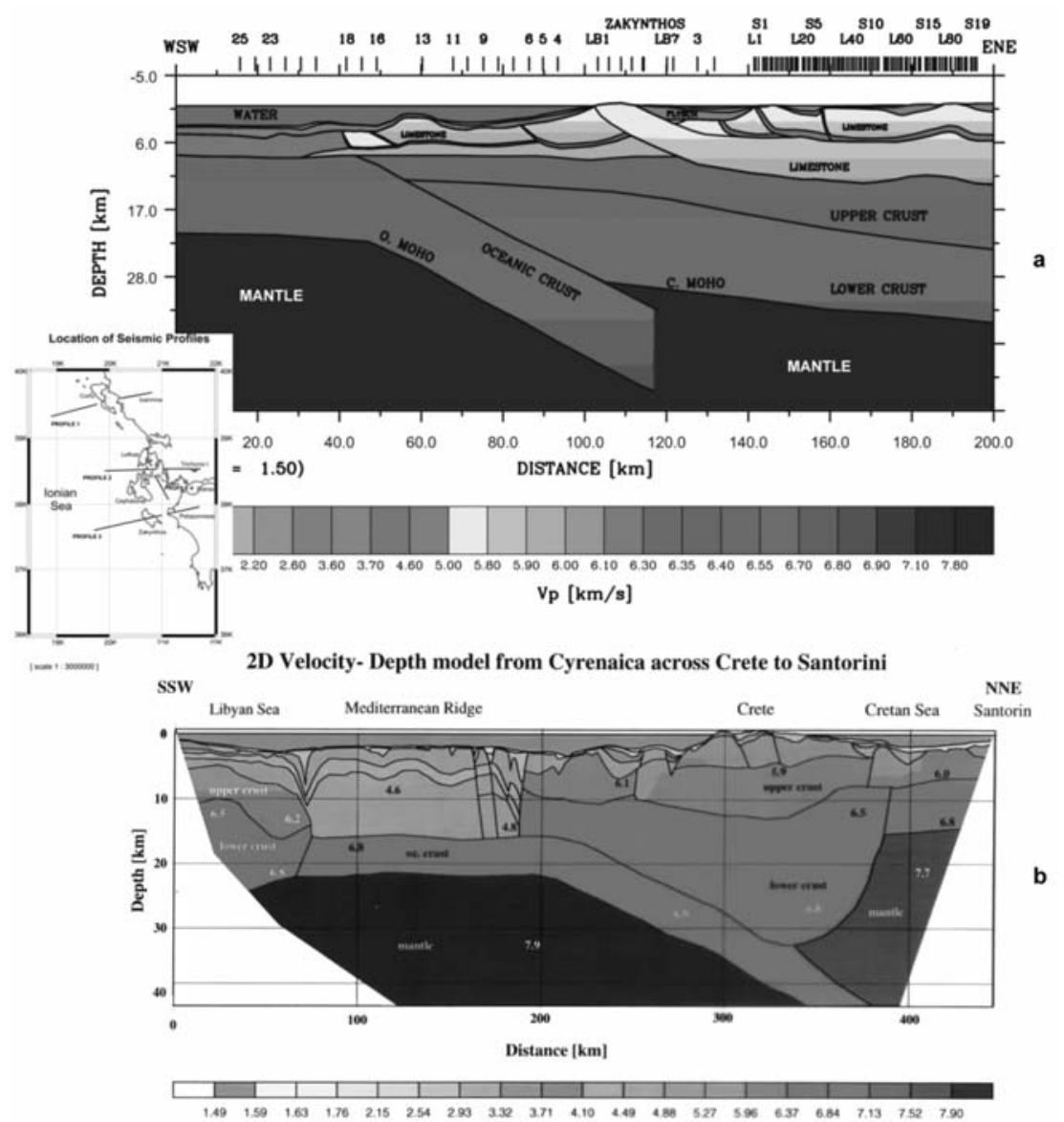

Fig. 2: Examples of crustal cross sections derived by active seismic experiments: a) Makris and Papoulia (2009), b) Makris and Yegorova (2006).

In summary, the crust mapped is very variable in thickness. The western Hellenides on mainland Greece and the Peloponnese exceed $40 \mathrm{~km}$, while the Cretan Sea at its thinnest part is only $16 \mathrm{~km}$ thick. The eastern Cyclades are $26 \mathrm{~km}$ thick and the crust under north Evia, confirmed also by the Evia experiment of 1996, (Makris et al. 2001) is $30 \mathrm{~km}$ thick.

The velocity of the compressional waves $\mathrm{Vp}$ at the Moho level is below the Cyclades, Evia and the Cre$\tan$ Sea $7.7 \pm 0.1 \mathrm{~km} / \mathrm{s}$ and therefore significantly lower then the values obtained below the Peloponnese and Western Greece, where Vp velocity at Moho level is normal with $\mathrm{Vp}=8.0 \pm 0.1 \mathrm{~km} / \mathrm{s}$. The low Vp-velocity below the Aegean Sea is due to the subduction of the oceanic lithosphere of the Ionian plate below the continental domain of the Aegean microplate and the mobilisation of the asthenosphere that has intruded the Aegean region at crustal levels. This is also expressed by the Aegean volcanic activity and its subcrustal seismicity (see e.g. Papazachos and Papazachou 1997, Makropoulos 1978, Galanopoulos 1975). Crete is $32 \mathrm{~km}$ thick at the western side, $34 \mathrm{~km}$ at its centre, and thins to 26 at the eastern side of the Island. Pn is $7.7 \mathrm{~km} / \mathrm{s}$ at the eastern side of the Island and $8.0 \mathrm{~km} / \mathrm{s}$ at the western. Finally, the profile representing the Dodecanese area has crustal thickness of about 23 to $24 \mathrm{~km}$ below Rhodes and Nisyros, thinning to the southwest to about $18 \mathrm{~km}$ at the eastern Cretan Sea. 


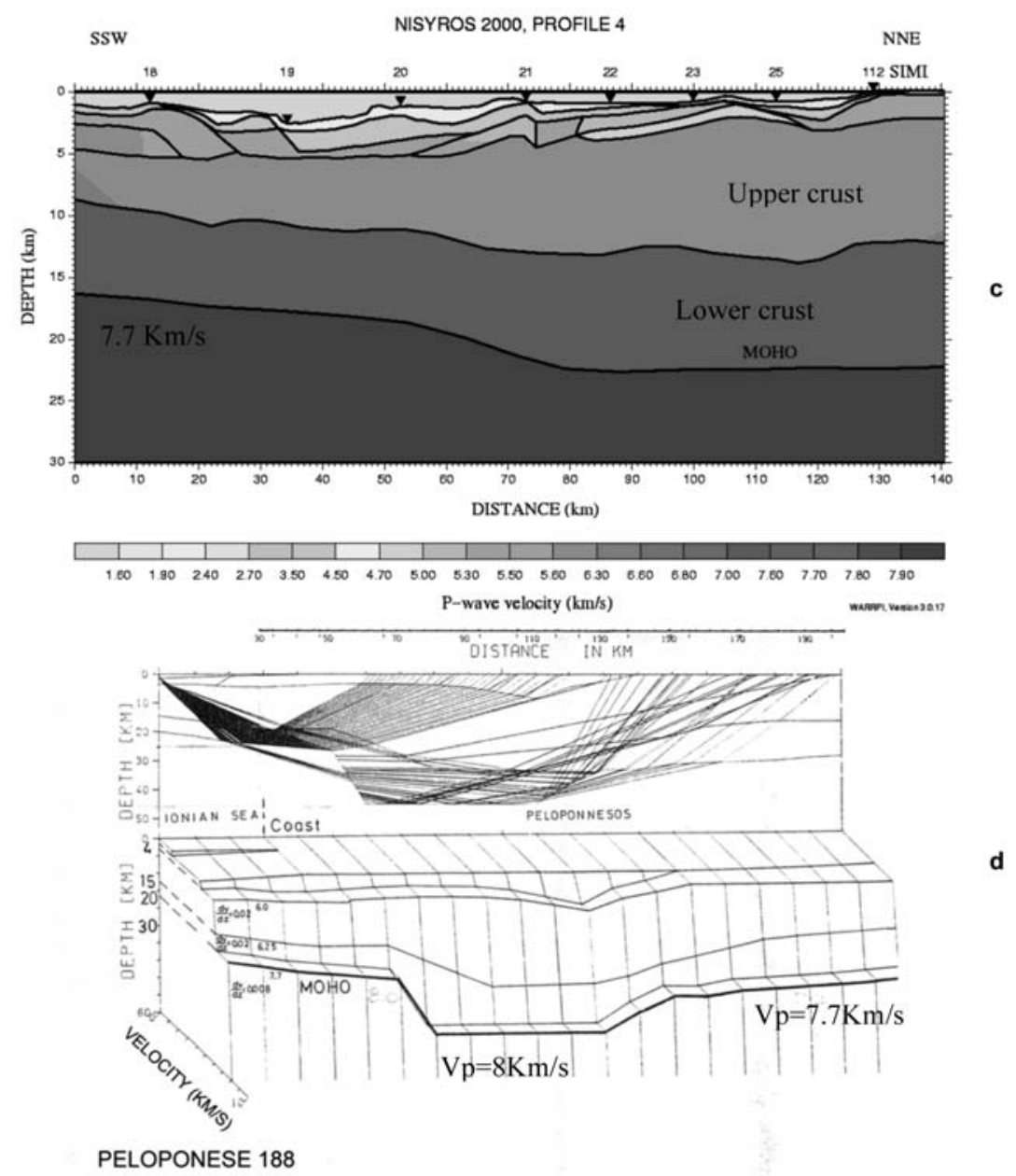

Fig. 2 cont.: Dodecanese, Peloponnese: c) Makris and Chonia (2000), d) Makris (1978).

These seismic crustal profiles were further used to develop a 3-D velocity-density model of Greece by combining them with the gravity field. They have been also exploited to map faults and delineate the tectonic elements that formed the Hellenides. Papoulia and Makris, this volume, present an example of how active seismic data are used to map the main tectonic elements of a region. The procedure followed to obtain 3-D earth models from the 2-D seismic results is schematically presented below:

-2D-active seismic data provide Vp, Vs and $v$ models ( $v=$ Poisson ratio).

Empirical functions between Vp and density Q (Birch, 1961, 1962;

Nafe and Drake, 1973).

$\downarrow$

- 2D-density models are computed, constrained by 2-D seismic models and the velocity-density empirical functions (2D-gravity modelling).

Empirical functions between Vp and density @ (Birch, 1961, 1962;

Nafe and Drake, 1973). 
- 3D- density models are computed, constrained by the 2-D $\rho$-models and the $\Delta \mathrm{g}$ '”- gravity field (3D gravity modelling).

- 2D and 3D isostatic models are derived from the density model and the g-values of the regional gravity mapping.

- 2D and 3D distribution of the temperature field is computed from the density models and the mapped heat flow density distribution.

$\downarrow$

The models derived by this procedure can be further used to obtain 3-D velocity models, relocate the regional seismicity and define active faults, permitting to compute seismic hazard reliably.

\section{Gravity data and gravity maps of Greece}

The regional gravity and magnetic mapping of Greece was accomplished using five to seven crews. Each group consisted of two to three observers and was equipped with: 1 gravity meter (LaCoste and Romberg, Type G), 1 magnetic torsion balance (vertical component, Type Askania), 3 altimeters (Thomen 3 B-4), and 1 aspirated hygrometer. The crews were provided by the following institutions: In 1971: Institute of Geophysics, University of Hamburg (IfG) (Dr. Makris), 3 groups, National Institute of Geology and Mining Researches (IGME), Athens, Greece (Dr. Stavrou), 1 group, Institute of Geodesy, Technical University of Athens (Prof. Veis), 1 group. In 1972: IfG - 4 groups, IGME, Athens, Greece - 1 group, Institute of Physical Astronomy, University of Thessaloniki - 2 groups. In 1973: IfG - 3 groups, IGME, Athens, Greece - 1 group. Officers of the Hellenic Army, Department of Geographic Service (GYS), supported the field parties. Evaluation, reduction and compilation of the data into maps were performed at the University of Hamburg. Gravity data were tight to the first order gravity net established by GYS and the above mentioned institutions and is connected to the European Calibration Line at the Frankfurt Airport. Gravity anomalies are given in form of Bouguer values and presented in a map of $25 \mathrm{mGal}$ isolines (Fig. 3).

The following formulae were used for the reductions and calculation of the free air $\left(\Delta \mathrm{g}^{\prime}\right)$ and Bouguer $(\Delta \mathrm{g}$ ") anomalies:

$\Delta \mathrm{g}^{\prime}=\mathrm{g}-\gamma+\delta \mathrm{g}_{\mathrm{F}}, \Delta \mathrm{g}^{\prime \prime}=\Delta \mathrm{g}^{\prime}+\delta \mathrm{g}_{\mathrm{T}}+\delta \mathrm{g}_{\mathrm{B}}$

$\mathrm{g}=$ measured gravity adjusted to the gravity net which was connected to Athens, East Air Terminal Station A: $g=980,058.28 \pm 0.08 \mathrm{mGal}$.

$\gamma=$ theoretical gravity according to the International Formula 1967.

$\delta g_{\mathrm{F}}=$ Free-Air reduction $=0.3086\left(\mathrm{~h}_{\mathrm{s}}-\mathrm{h}_{\mathrm{o}}\right) \mathrm{mGal}$ with:

$\mathrm{h}_{\mathrm{s}}=$ altitude of the gravity station, $\mathrm{h}_{\mathrm{o}}=$ reduction level $=0_{\mathrm{m}} \Rightarrow$

$\delta g_{B}=$ Bouguer reduction; the Bouguer masses are reduced spherically to Hayford Zone $\mathrm{O}_{2}(166.7$ $\mathrm{km}$ ), with uniform density of $2.67 \mathrm{gr} / \mathrm{cm}^{3}$ according the formula given by Cassinis, Dore and Ballarin (1937).

$\delta g_{\mathrm{T}}=$ topographic reduction, computed with constant density $\rho=2.67 \mathrm{gr} / \mathrm{cm}^{3}$ in a system of geographic coordinates according the equations of Nagy (1966) and Jung (1961).

Reduction techniques for computing gravity anomalies have been described extensively by Makris (1971). The results of the computations are given in Fig. 3. Data at sea were taken from Allan and Morelli (1971) and Finetti and Morelli (1973). The Aegean Sea was mapped by gravity and magnetic surveys in 1982 by the R/V - Sonne and 1983 and 1984 by the R/V-AEGEAO. This was in cooperation between IfG-Hamburg, that provided the instruments and know-how and the HCMR-Athens that provided the R/V-AEGEAO. Crete was resurveyed in 1999 and 1998 by establishing 2000 gravity and 


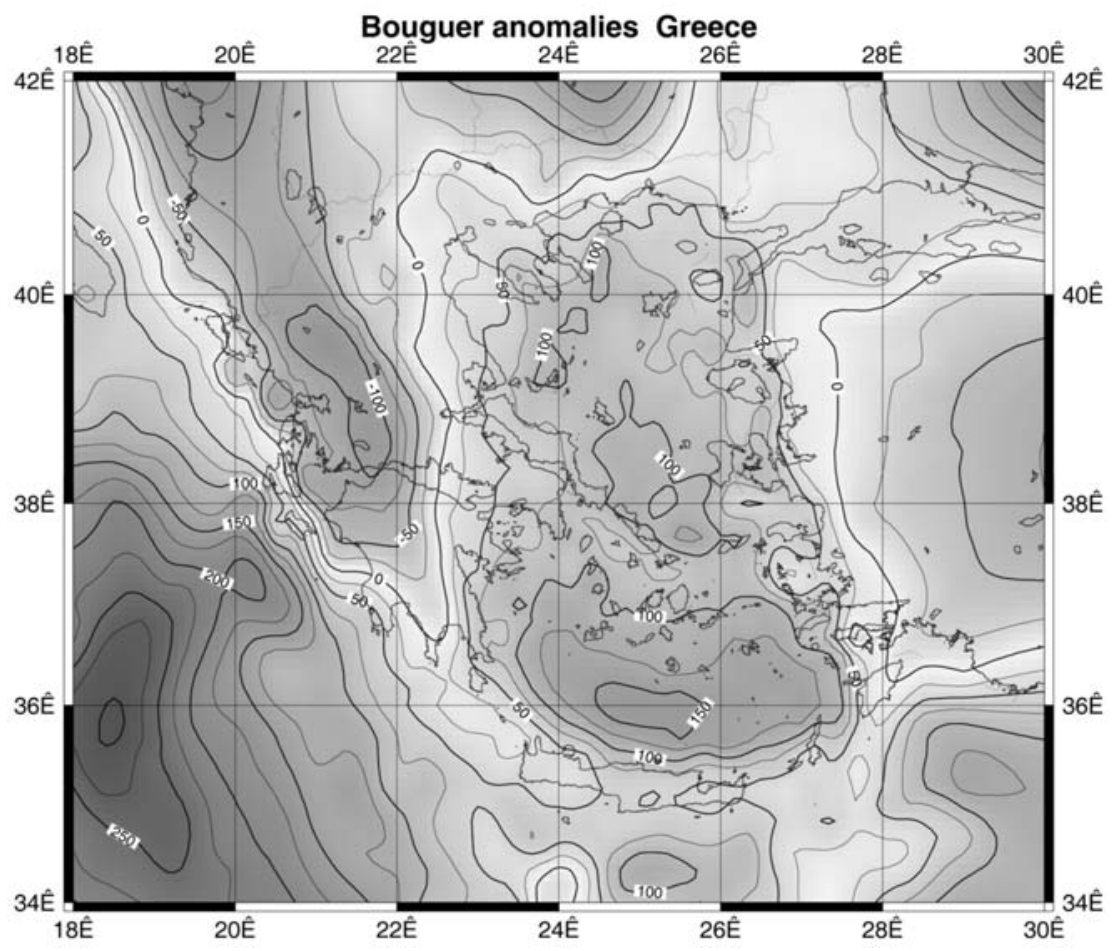

Fig. 3

magnetic stations on the Island by the universities of Hamburg and Bochum. For a discussion of the gravity surveys and their accuracy see Makris and Yegorova 2006, Makris et al. 2001, Makris 1978 and Makris et al. 1973.

A significant number of gravity stations has been additionally mapped by PPC-Athens in western Greece and in the geothermal areas of Lesvos, North Evia, the Serrais basin and the LoutrakiSousaki zone by IGME in cooperation with the university of Hamburg. The land gravity data exceed 26.000 stations.

\section{A qualitative description of the Bouguer gravity field and a 3-D density model}

The Hellenic region can be divided into two gravimetric provinces. One is the western Greece with negative gravity values (gravity anomalies refer always to Bouguer gravity). The other is the Aegean region, Crete and the eastern part of Greek Mainland, where the gravity field is positive.

The zone of the negative anomalies of the Hellenides (Fig. 3) has minimum values of $-120 \mathrm{mGal}$ with local minima of up to $-140 \mathrm{mGal}$ along the Pindos chains. At the northern Peloponnese (Gulf of Patras) we find values of -80 to $-120 \mathrm{mGal}$, which gradually become positive to the south towards the Gulf of Kalamata. The gravity zero line is nearly south north oriented from east Peloponnese to the Olympus Mountains, limiting the Aegean gravity high to the negative gravity low at the west. Eastern Greece, the Aegean Sea and Crete have positive gravity anomalies increasing from $+50 \mathrm{mGal}$ in the north to $+160 \mathrm{mGal}$ in the south. Maximum values are reached at the Cretan Sea at approximately $36^{\circ} \mathrm{N}$ between $24-26^{\circ} \mathrm{E}$ ranging locally from +150 to $+170 \mathrm{mGal}$. 

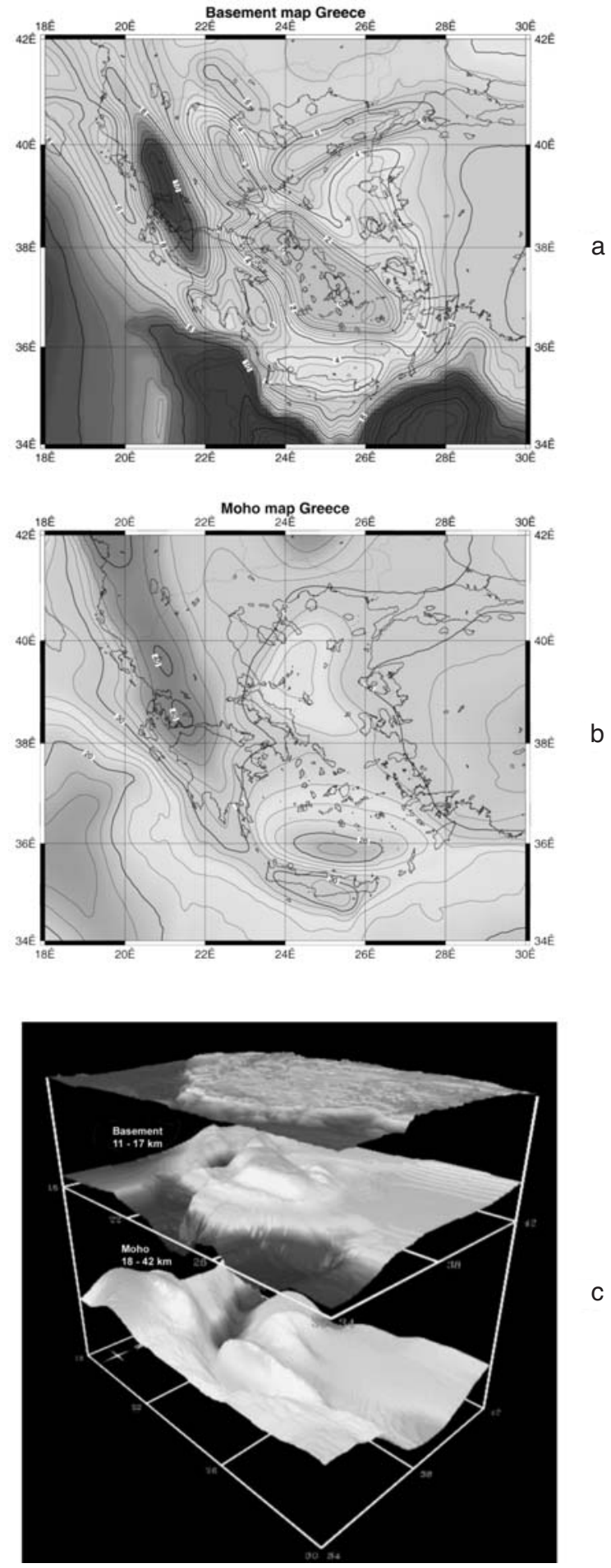

Fig. 4

XLIII, No $1-38$ 
The 3-D density model presented in figure $4 \mathrm{a}, \mathrm{b}, \mathrm{c}$ is computed by a procedure developed by Tchernysev and Makris (1996), based on the algorithm published by Talwani et al. (1959). The model is discriminated in prisms of $5 \times 6 \times 0.5 \mathrm{~km}$ and the initial geometry and density were constrained by the seismic models located in figure 1 . Velocities define the density values using the empirical functions between velocity and density published by Birch (1960 and 1961) and Nafe and Drake (1973). A detailed report on the computation of the 3-D density-velocity model of southern Greece and the Libyan Sea is published by Makris and Yegorova (2006) and a second covering all the country is in preparation by Makris, Yegorova, Papoulia, (2010).

In figure $4 \mathrm{a}$ and $\mathrm{b}$ the basement and the Moho maps are presented. Thick sediments, exceeding $6 \mathrm{~km}$ were mapped at the North Aegean Trough, the Thermaikos Basin and particularly in western Greece below the external Hellenides, where the sediments are up to $10 \mathrm{~km}$ thick. It is also interesting that the largest accumulation of sediments were mapped SE and SW of Crete at two 12 to $14 \mathrm{~km}$ deep depressions, separated by a basement high extending south of Crete for more than $100 \mathrm{~km}$.

Crustal thickness has its maximum value with 40 to $42 \mathrm{~km}$ below Pindos. The northern and central Aegean Sea is about 24 to $26 \mathrm{~km}$ thick and the Cretan Sea 16 to $20 \mathrm{~km}$. Crete is $30 \mathrm{~km}$ thick at the west, thickens at the central part of the Island to $34 \mathrm{~km}$ and thins again at the east to about $26 \mathrm{~km}$. The crust at Western Turkey thickens to about 30 to $34 \mathrm{~km}$ (see also Saunders et al. 1998), while the crust of the Ionian Sea at the backstop, between the western Peloponnese coast and the Mediterranean Ridge is about $24 \mathrm{~km}$ thick and floored by thin continental crust. The oceanic part of the Ionian Sea is only 14 km thick, with sediments of more than 6 km (see also Fineti 1982 and Fineti and Morelli 1973). Crustal thickness obtained on continental Greece by Sodouti et al. (2006) from P and S receiver functions are in good agreement with our results. The crustal thickness map (Moho map) however, they published by interpolating isodepth lines between the values obtained at the different stations is very irregular and differs from the Moho map of Makris, Yegorova, Papoulia (2010) of figure 4. The reason is, that they used a very limited number of stations (65 points) and the interpolated lines are inaccurate.

In figures $5 \mathrm{a}$ and $5 \mathrm{~b}$ two crustal cross sections of $\mathrm{E}-\mathrm{W}$ and $\mathrm{N}-\mathrm{S}$ orientation were extracted from the 3Ddensity model. In both sections a low density-velocity body below the Aegean Sea was modelled, extending from Crete to the North-Aegean Trough and from East Peloponnese to western Turkey. This anomalous body, with more than $50 \mathrm{~km}$ thickness, is part of the asthenosphere mobilized by the subduction of the Ionian oceanic lithosphere below the Aegean continental domain. It is the source of high heat flow through the Aegean crust and feeds with magma the volcanoes of eastern Greece. The magma generated and mobilized from this low velocity-density intrusion ascends to the surface through zones of crustal weakness. Thus, the volcanoes of Santorini, Colombo and Melos as Makris and Papoulia (2009) showed, are located at the transition of the stretched crust of the Cretan Sea, to the thicker crust of the Cyclades which is build by a series of thrusts, seismically active, as Bonhoff et al. (2006) showed. In the same way the volcanic and the hydrothermal activity at the North Evia Gulf are located at the transition of the thin crust of $20 \mathrm{~km}$ in the Gulf (Makris et al. 2001) to the $30 \mathrm{~km}$ crust of north Evia (Makris and Vees 1977 and Makris et al. 2001).

The density model presented above can be used for considering the isostatic behaviour of the crust and mantle system and associate it with the tectonic deformation and the seismicity. It can be also used to constrain modelling of the distribution of the isotherms from the heat flow density map, published by Čermak (1979) and presented in figure 7. In figure 6 the pressure in Kbar of the masses that are between 0-20, 0- 40 and 0-60 km depth was calculated. As seen the upper $20 \mathrm{~km}$ of the crust and sediments between the Ionian Sea and the Hellenides is not isostatically balanced. The transition between the Ionian Sea and the Peloponnese shows a lateral change from 4.2 to 5.6 Kbar. It is therefore not sur- 


\section{Density model - Greece - pr.2 WE}

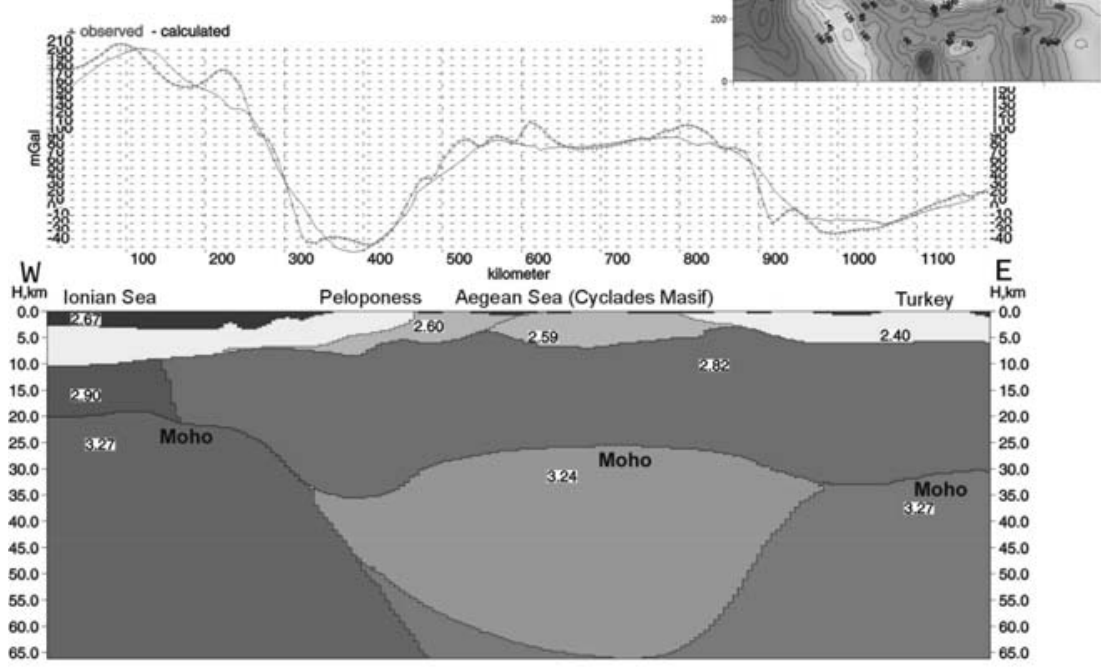

Fig. 5: a. E-W crustal cross section between the oceanic domain of the Ionian Sea and the continental domain of the Aegean microplate.

\section{Density model - Greece - pr.2 SN}
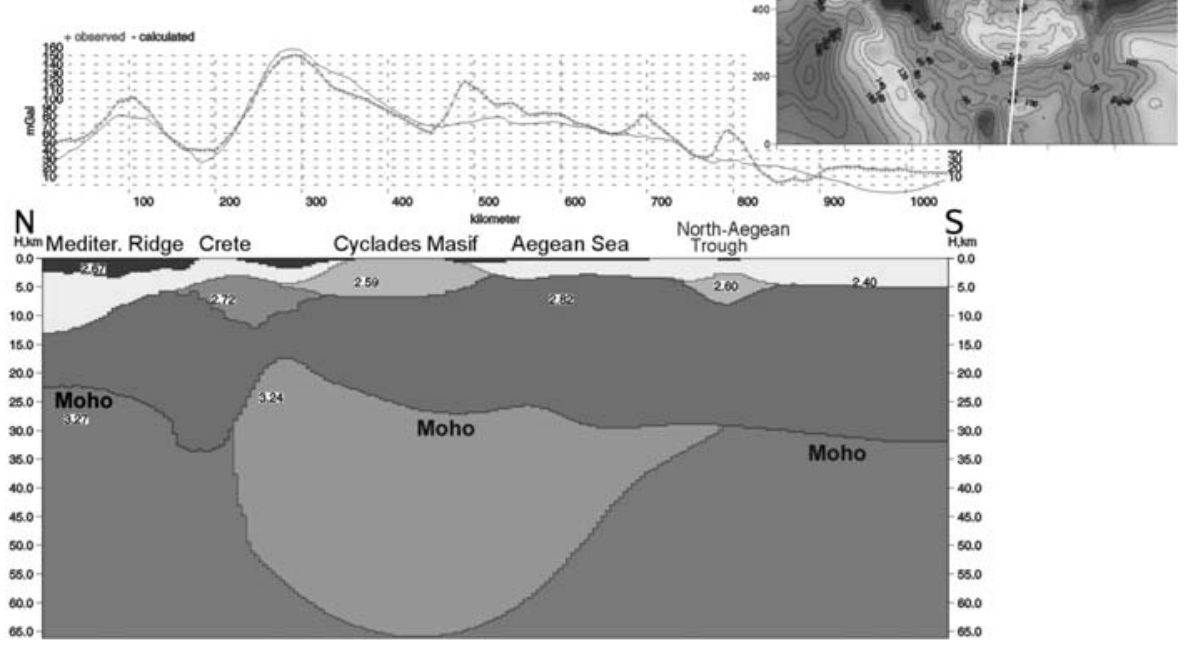

Fig. 5: b. N-S cross section between the Libyan Sea and the northern Aegean Sea. 


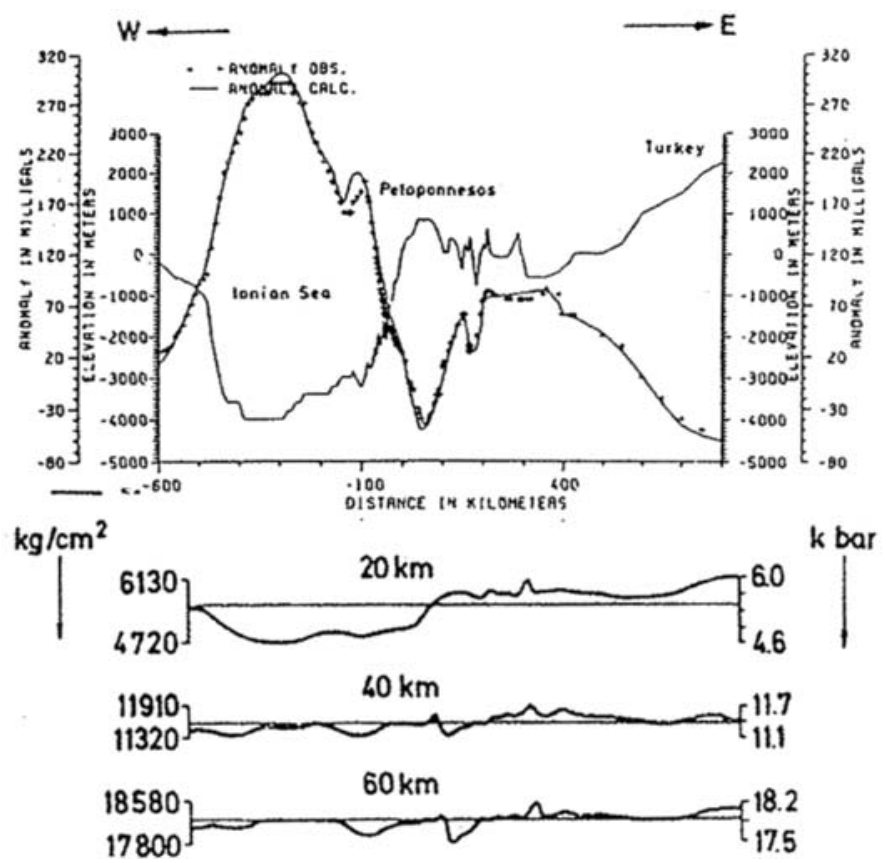

Fig. 6: Mass and pressure distribution at three different levels along an E-W profile between the Ionian Sea and western Turkey (Makris, 1977).

prising that the area with the greatest isostatic disturbance and lateral pressure variation has also significant seismicity at crustal levels. At $40 \mathrm{~km}$ and even more so at $60 \mathrm{~km}$ depth the regional isostatic balance is established. There are two areas, which remain disturbed. The one is at the transition of the Mediterranean Ridge to the backstop, due to the large difference of the sedimentary thickness. The other is at the central Peloponnese area where the crust is thickened to nearly $40 \mathrm{~km}$ and the dense mantle displaced. In both cases we have a significant deficiency of mass.

\section{Heatflow density map of the Hellenides and distribution of the isotherms}

The heat flow density map presented in figure 7 was compiled by Čermak (1979). Since then only few measurements, mainly concentrated at geothermal areas or boreholes of the oil industry, have been added. The regional features therefore have not changed. The Aegean region including the Saronikos and Evoikos Gulfs are of high heat flow density. The heat flow density values exceed 1.6 HFU (Heat Flow Units) and indicate that the crust alone cannot explain the observed field by the heat generation of the continental crust. The mantle transports heat by conduction and convection of a lithothermal system mobilized by the subduction of the Ionian oceanic lithosphere below the Aegean micro continent. The Aegean Sea, south of the North Aegean Trough and the western part of Turkey are areas of high heat flow. In the contrary, the eastern Mediterranean region and the largest part of the Ionian Sea have HFU $<0.9$ and are well below average. The crust is mainly oceanic and therefore of low heat production and the upper mantle is cold and has a small input into the heat flow density field. Using the one dimensional heat conduction equation:

$$
\mathrm{T}(\mathrm{z})=\mathrm{T}(\mathrm{o})+\mathrm{Qo} / \mathrm{k} * \mathrm{z}-\mathrm{A} / 2 \mathrm{k} * \mathrm{z}^{2}
$$

where " $\mathrm{Q}_{0}$ " is the heat flow density value through the earth surface, " $\mathrm{k}$ " is the thermal conductivity and 


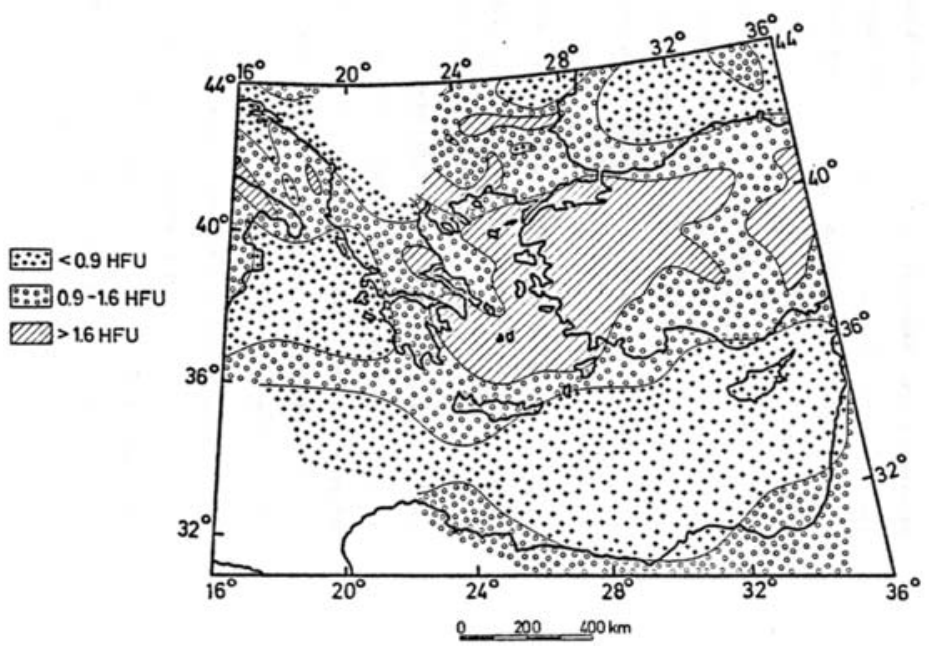

Fig. 7

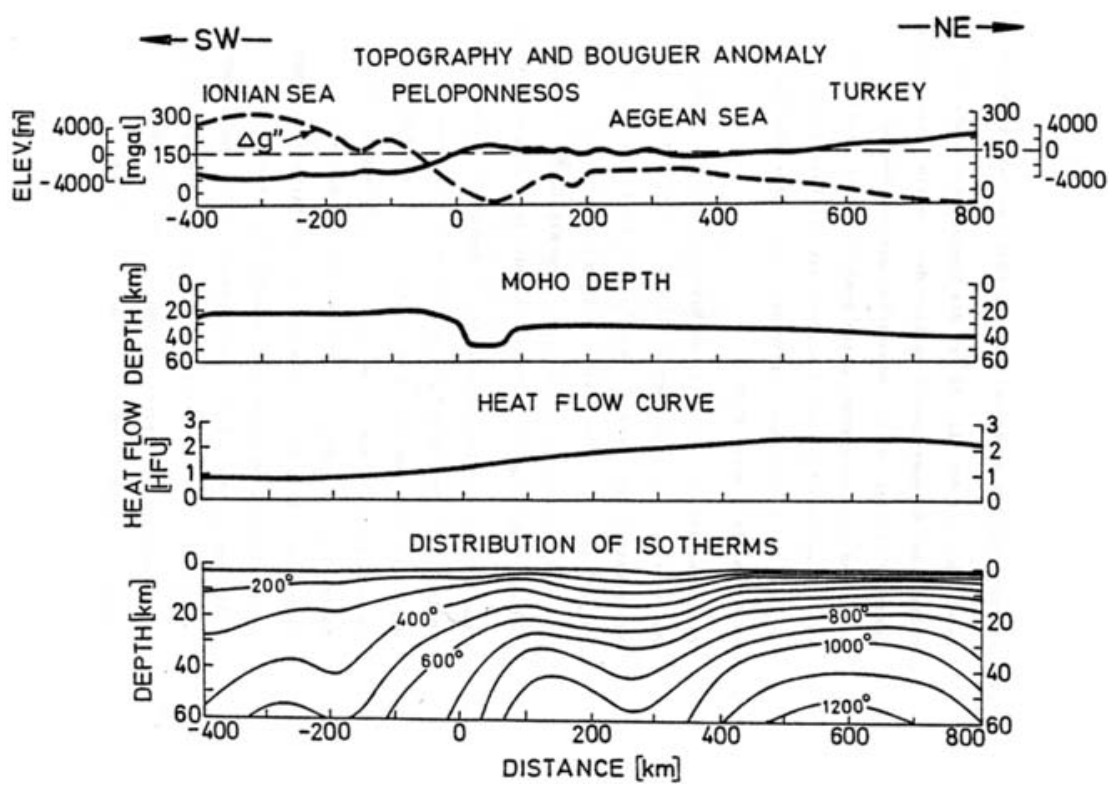

Fig. 8: Calculated isotherms in ${ }^{\circ} \mathrm{C}$. For further explanations see text.

"A" is the heat production, we can compute the temperature distribution as a function of depth constrained by the density models.

In figure 8 the distribution of the isotherms between the Ionian Sea and western Turkey are presented. In the figure the crustal thickness along the profile, the smoothed heat flow density curve and the corresponding distribution of the isotherms are presented. It is interesting to see that e.g. the $400^{\circ} \mathrm{C}$ isotherm, which at the deep part of the Ionian Sea is between 40 to $60 \mathrm{~km}$ depth below the Aegean 


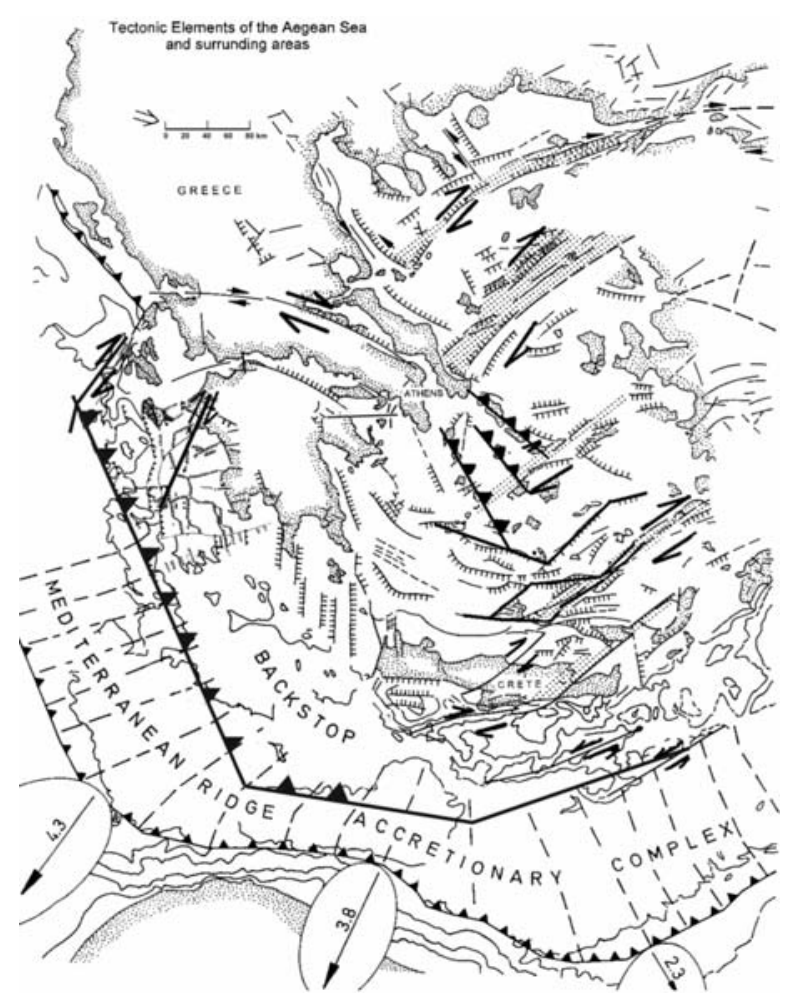

Fig. 9: Simplified schema of the dominant tectonic regions in the Aegean Sea and the western Hellenides.

Sea, is encountered at only $10 \mathrm{~km}$ depth. It is therefore not surprising, that all thermal phenomena either in form of volcanoes or as hydrothermal systems are confined within the Aegean region and western Turkey. As stated previously, the volcanoes are linked with deep-sited faults and are confined at the transition of thin to thick crust. The hydrothermal systems are either linked to volcanoes and their magma intrusions or to deep faults that permit penetration of to surface waters to the heated rocks. Heated fluids of various temperatures are transported back to the surface by convection.

\section{The main tectonic elements mapped by active seismic profiles}

The simplified schema of the main tectonic elements as were mapped by the active and passive seismic data, delineate two different tectonic regions. The eastern north Aegean Sea is directly associated with the dextral wrench fault system of north Anatolia. Seismicity is extremely intense along the strikeslip faults and earthquake magnitudes can obtain destructive values. All this activity is linked to crustal deformation by transtension and transpression accompanied mainly by normal faulting. The same is valid for the Cretan Sea and part of the Dodecanesse, although the seismicity is less intense than that of the north Aegean area. It is only south of Crete at the Ptolemeus, Pliny and Stravo trenches that the strike-slip processes become sinistral in order to accommodate the northeastern motion of the African Plate that is subducted below southwestern Turkey. Crustal seismicity dominates also the western Hellenides. We could map the extension of the continental Aegean microplate to the west, up to the eastern limit of the Mediterranean Ridge. This is also the location where the Ionian Oceanic lithosphere is subduced below continental Hellenides. Thrusting and crust shortening is the dominant tectonic process, accompanied by normal faulting that accommodates the westwards thrusted crustal units. Dextral strike-slip is dominant along the Cephalonia and Andravida Faults, displacing the Hellenides to the 
west. Deep seismicity is mapped only below the Aegean volcanoes, due to subduction of the Ionian oceanic lithosphere. Shallow seismicity mapped at the Cyclades on the other hand, is linked to the crustal deformation that created the Cyclades by thrusting and regional upcoming due to isostatic buoyancy caused by the low velocity-density mantle below the central Aegean Sea. The exhumed HP-rocks at the Cyclades developed as a consequence of the small-scale Mediterranean region subduction of an inhomogeneous incoming lithosphere, causing chaos in the subduction process with subsequent retreat of the subduction front (see Husson et al. 2009, Royden and Husson 2006 or Jolivet at al. 2008).

\section{Acknowledgements}

I want to thank Mrs. J. Mertins and Mrs. M. Toma for their help in the preparation of the text and figures. Dr. J. Papoulia (HCMR) read the manuscript critically and her help and remarks are highly acknowledged.

\section{References}

Allan, T.D., Morelli, C., 1971. A geophysical study of the Mediterranean Sea, Boll. Geofis. Teor. Ed. Appl., 13, No.50, pp. 99-141, Triest.

Berckhemer, H., 1970. MARS 66- a magnetic tape recording equipment for deep seismic sounding, Zeitschriftf. Geophys. 36, 501-518.

Birch, F., 1960/61. The velocity of compressional waves in rocks to 10 kilobars, J. Geophys. Research 56, 66.

Bonhoff, M., Makris, J., Papanicolaou, D., Stavrakakis, G., 2001. Crustal Investigations of the Hellenic Subduction Zone Using Wide Aperture Seismic Data. Tectonophysics 343, pp. 239 - 262.

Bonhoff, M., Rische, M., Meier, T., Becker, D., Stavrakakis, G., Harjes, H.P., 2006. Microseismic activity in the Hellenic Volcanic Arc, Greece, with emphasis on the seismotectonic setting of the Santorini- Amorgos zone. Tectonophysics 423, pp. 17-33.

Cassinis, G., Dore, P., Ballarin, S., 1937. Fundamental tables for reducing gravity observed values. R. Commissione Geodetica Italiana Pubblicazioni, Nuove serie, n. 13.

Čermák, V., 1979. Heat flow map Europe. In: V. Čermák and L. Rybach (Editors), Terrestrial Heat Flow in Europe. Springer Verlag, Berlin, Heidelberg, New York, pp. 3-40.

De Voogd, B., Truffert, C., Chamot-Rooke, N., Huchon, P., Lallement, S., Le Pichon, X., 1992. Two ship seismic soundings in the basins of the Eastern Mediterranean Sea (Pasiphae Cruise). Geophys J. Int., $109,536-552$.

Finetti, I., 1982. Structure stratigraphy and evolution of the central Mediterranean Sea. Boll. Di Geofisica Teorica ed Appl. XV, 60.

Finetti, I., Morelli, C., 1973. Geophysical exploration of the Mediterranean Sea. Boll Geof. Teor. Appl., 15, 263-344.

Galanopoulos, A.G., 1975. A new model accounting for the intermediate earthquakes at the convec. side of the Hellenic arc, Ann.Geol.d.Pays Hellen., 27, 355-370.

Ginzburg, A., Makris, J., Hirschleber, H.B., 1987. Geophysical Investigations in the North Aegean Trough. Annales Geophysicae, 5B, 167-174.

Husson, L., Brun, J-P., Yamato, Ph., Faccenna, C., 2009. Episodic slab rollback fosters exhumation of HPUHP rocks. Geophys. J. Int. 179, 1292-1300.

Jolivet, L. et al., 2008. Subduction, convergence and the mode of backarc extension in the Mediterranean region. Bull. Soc. Geol. France, 179, 525-550.

Jung, K., 1961. Schwerkraftverfahren in the Angewandten Geophysik. Akademische Verlagsgesellschaft Geest \& Portig KG.

Makris, J., 1978. The Crust and Upper Mantle of the Aegean Region from Deep Seismic Soundings. 
Tectonophysics 46, 251-268.

Makris, J., 1978. A Geophysical Study of Greece based on Deep Seismic Studies, Gravity and Magnetics. in Alps, Appenines, Hellenides (ed. H.Closs, D.Roeder, K.Schnüdt): 415-423, Stuttgart Schweitzerbart'sche Verlagsbuchhandlung.

Makris, J., Chonia, T., 2000. Active and Passive Seismic Studies of Nisyros Volcano - East Aegean Sea. Communications of the Dublin Institute of Advanced Studies. Series 1, Geophysical Bulletin Nr 4.

Makris, J., Mavrides, L.N., Menzel, H., Stavrou, A., Veis, G., 1973. The Gravity Field of Attika, the Peloponnesos and Kithira. Z.f.Geophys., 39, 929-936.

Makris, J., Papoulia, J., Papanikolaou, D., Stavrakakis, G., 2001. Thinned continental crust below northern Evoikos Gulf, central Greece, detected from deep seismic soundings. Tectonophysics, 341, 225-236.

Makris, J., Papoulia, J., 2009. Tectonic Evolution of Zakynthos Island from deep Seismic Soundings: Thrusting and its Association of the Triassic Evaporites. Intl. Symposium and Field trip Evaporites: Sedimentology, Evaluation and Economic Significance, Zakinthos, Greece, 47-54.

Makris J., Papoulia, J., 2009. The Thera Volcano at the transition between the Cycladic thrust belt and the stretched continental crust of the Cretan Sea. The Atlantis Hypothesis: Searching for a Lost Land. $2^{\text {nd }}$ International Conference, Athens, November 2008. Proceedings of the ATLANTIS 2008 International Conference.

Makris, J., Thiessen, J.,1983. Offshore Investigations of the Sedimentary Basins with a newly developed Ocean Bottom Seismograph. In Expanded Abstracts, 53rd Annual International SEG Meeting, Las Vegas: $470-473$.

Makris, J., Vees, R., 1977. Crustal Structure of the Central Aegean Sea and the Islands of Evia and Crete, Greece, obtained by Refraction Seismic Measurements. J.Geophys, 42, 329-341.

Makris, J., Weigel, W., Koschyk, K., 1977. Crustal Models of the Cretan Sea deduced from Refraction Seismic Measurements and Gravity Data. In Meteor Forschungsergebnisse Reihe C, 27.

Makris, J., Yegorova, T., 2006. A 3-D density-velocity model between the Cretan Sea and Libya. Tectonophysics, 417, 201-220.

Makris, J., Yegorova, T., Papoulia, J., 2010. A3-D density-velocity model of Greece deducted from gravity and active seismic data. To be submitted to Geoph.J. Int.

Makropoulos, K.C., 1978. The statistics of large earthquake magnitude and an evaluation of Greek seismicity, "PhD. Thesis", Edinburg University, 193 pp.

Nafe, J.E. and Drake, C.L., 1973. Physical properties of marine sediments in: The Sea, Vol. 3, Ed. M.N. Hill. Interscience, pp. 794-814.

Nagy, D., 1966. The gravitational attraction of a right rectangular pris. Geophysics VXXXI.

Papazachos, B., Papazachou, C., 1997. The earthquakes of Greece. P.Ziti \& Co, Thessaloniki, Greece.

Papoulia, J., Makris, J., 2010. Tectonic processes and crustal evolution on/offshore western Peloponnese derived from active and passive seismics. Bull. Geol. Soc. Greece 2010, submitted.

Royden, L., Husson, L., 2006. Trench motion, slab geometry and viscous stresses in subduction systems. Geophys. J. Int., 167, 881-905.

Saunders, P., Priestley, K., Taymaz, T., 1998. Variations in the crustal structure beneath western Turkey. Geophys. J. Int., 134, 373-389.

Sodouti, F., Kind, R., Hatzfeld, D., Priestley, K., Hanka, W., Wylegalla, K., Stavrakakis, G., Vafidis, A., Harjes, H.P., Bonhofff, M., 2006. Lithospheric structure of the Aegean obtained from P and S receiver functions. J. Geophys. Res., Vol. 111.

Talwani, M., Sutton, G.H., Worzel, J.L., 1959. A Crustal Section across the Puerto Rico Trench, I. Geophys. Res., 64/10.

Tchernychev, M., Makris, J., 1996. Fast Calculation of Gravity and Magnetic Anomalies Based on 2-D and 3-D Grid Approach. Extended Abstract of the 66th SEG-Meeting. Denver. 